\title{
Prevalence of Oncogenic Human Papillomavirus in Pregnant Adolescents, Association With Colpocytological Changes, Risk Factors and Obstetric Outcomes
}

\author{
Henrique Diório de Souza \\ Universidade de São Paulo \\ Adriana Lippi Waismann \\ Universidade de São Paulo \\ Giselle Rodrigues Mota Diório \\ Universidade Federal de Juiz de Fora \\ Stela Verzinhasse Peres \\ Fundação Faculdade de Medicina \\ Rossana Pulcineli Vieira Francisco \\ Universidade de São Paulo \\ Marco Aurélio Knippel Galletta ( $\square$ marco.galletta@fm.usp.br) \\ Universidade de São Paulo https://orcid.org/0000-0002-0016-1803
}

\section{Research Article}

Keywords: Papillomavirus Infections, Papanicolaou Test, Sexual Behavior, Disease Prevention, Pregnancy in Adolescence, Prenatal Care

Posted Date: February 15th, 2022

DOI: https://doi.org/10.21203/rs.3.rs-1013906/v1

License: () (1) This work is licensed under a Creative Commons Attribution 4.0 International License. Read Full License 


\section{Abstract}

Purpose: We aim to carry out an investigation on the impact of cervical oncogenic human papillomavirus (HPV) infection in pregnant adolescents, to clarify the prevalence and risk factors, considering the importance and lack of data on this topic in Brazil.

Methods: A cross-sectional study was conducted with adolescents receiving specialized prenatal care in a tertiary hospital in São Paulo, Brazil. On the first prenatal visit, were performed an oncotic colpocytological exam and an oncogenic-HPV assessment of the uterine cervix. We sought the association these exams with demographic and obstetric variables.

Results: A total of 303 pregnant adolescents whose mean age was $15.30 \pm 1.22$ years comprised the study subjects. The prevalence of high-risk HPV cervical infection was $50.50 \%$. Multivariate analysis revealed that a large number of partners in their lifetime (OR=1.268) and having a religion $(\mathrm{OR}=2.054)$ were risk factors for oncogenic HPV-caused cervical infection, while schooling appeared as a protective factor (OR=0.847). There was an association between Oncogenic HPV infection and colpocytological alterations, reaching almost $30 \%$ of patients. There was no association between Oncogenic HPV infection and obstetric outcomes

Conclusion: The prevalence found is one of the highest in Brazil and worldwide. A greater number of partners during their lifetime and having religion were detected as possible factors associated with cervical HPV infection. The findings of this study reinforce the need to implement measures of health education and prevention capable of modifying the incidence of cytopathological cervical lesions and of uterine cervix cancer in this population.

\section{Introduction}

The human papillomavirus (HPV) is a nonenveloped virus with an icosahedral capsid and a double-stranded DNA that induces intense cell proliferation. More than 120 types of HPV have been identified and approximately half of them infect the genital tract. They can be divided into low-risk and high-risk viruses according to their ability to cause oncogenic cytological abnormalities in the uterine cervix (1). Among the high-risk oncogenic viruses, we would like to mention the following subtypes: $16,18,31,33,35,39,45,51,52,56,58,59,67,68$, and 70 [1-4].

The cytological changes engendered by the human papillomavirus (HPV) were first reported in 1956 [5]. Today HPV is acknowledged as a necessary cause for the development of uterine cervix neoplasm. Cervical cancer ranks fourth among the cancers and it is the neoplasm with the largest incidence in women worldwide, except for the nonmelanoma skin neoplasms [6]. In 2017 it accounted for 6385 deaths in Brazil, corresponding to 1.11\% of the deaths of the female sex. In 2020 it was estimated that 16,590 new cases would occur, corresponding to 15.43 cases per 100,000 Brazilian women [7].

The HPV-caused infections tend to clear within 9 to 15 months [8]. Nevertheless, the infection may lie dormant in some women, and persist in a minority [8,9]. The independent risk factors associated with an HPV infection include the following: low educational level, first sexual intercourse at an early age, multiple sexual partners, multiple deliveries, smoking, patients younger than 30 years, alcohol consumption, partner belonging to an older age bracket, singlehood and the infrequent use or the absence of the use of barrier methods [10-19]. Prevalence of HPV in the uterine cervix of women in general varies from 7.3\% to $74.6 \%[20,21]$, whereas prevalence among adolescents is reported to be between $15 \%$ and $90 \%[22,23]$. On the other hand, prevalence of oncogenic HPV among adult women in general ranges from $5.3 \%$ to $54.3 \%$ in the literature $[20,21]$, whereas among adolescents the figures fall between $10.74 \%$ and $51.7 \%$ $[24,25]$. Some recent evidence appears to indicate that pregnancy has no bearing on prevalence, incidence, or HPV clearance [26]. However, other references state that hormonal and immunological changes related to pregnancy are associated with the activation of cervical HPV infection, increasing the risk of cervical dysplasia $[27,28]$.

The existence of evidence on a possible association between the gestational period and cervical HPV infection, as well as the existence of references informing about a higher rate of HPV isolation in young populations motivated this study $[12,15,27,28]$. There are few studies conducted with pregnant women to evaluate the high-risk HPV-caused infection of the uterine cervix. Research tends to be even scarcer when it comes to pregnant adolescents. Therefore, this study aimed to determine the frequency of occurrence and the risk factors associated with a diagnosis of cervical HPV infection in pregnant adolescents treated at an outpatient clinic for specialized prenatal care in a tertiary hospital in São Paulo, Brazil.

\section{Methods}

This observational cross-sectional study was carried out in a tertiary teaching hospital, the Hospital das Clínicas da Faculdade de Medicina da Universidade de São Paulo. The hospital is located in the city of São Paulo, the most populous metropolis in Brazil.

An analysis was performed of the medical and laboratory data of all of the pregnant adolescents aged 10 through 18 years admitted to the outpatient clinic for the prenatal care of pregnancy in adolescence of the Obstetric Clinic of the aforementioned hospital from January 01, 2010 to January 01,2016 . Excluded from the study were the pregnant adolescents who did not show up for prenatal care before the collection of vaginal smears, the adolescents with insufficient information in their medical records, or those with no access to it. Sociodemographic characteristics, clinical features, laboratory data, pathological history, obstetric history, and obstetric and neonatal outcomes were retrieved from the database of the sector. The adolescents' gestational ages were estimated using the first day of the last menstruation or the first ultrasound exam during prenatal care.

\section{Collection of material from the uterine cervix}

Investigation of HPV in the uterine cervix was usually performed during the first prenatal visit. The participants were subjected to a speculum examination for collecting cells from the ectocervix and the endocervix with a small brush. The material that was gathered was transferred to a glass slide for an oncotic colpocytology (Pap smear) test and to a specific liquid medium from the digene HC2 DNA Collection Device for detection of high-risk HPV. The search for HPV 
types was conducted with the digene $\mathrm{HC} 2$ High-Risk HPV DNA test using the Hybrid Capture ${ }^{2} 2(\mathrm{HC} 2)$ technology. The test is based on hybrid-capture strategies and the use of probes for detecting 13 viral subtypes of $\operatorname{HPV}(16,18,31,33,35,39,45,51,52,56,58,59$, and 68$)$.

\section{Data management and statistical analysis}

A database was built with the Microsoft Excel for Office 365 software. Statistical analyses were performed with the IBM SPSS Statistics for Windows 20.0 (IBM Corp., Armonk, NY) software.

Qualitative data were reported as measures of absolute and relative frequency (percentage) and compared by means of the chi-square test or the Fisher exact test as appropriate. Quantitative data were displayed as measures of central tendency (mean, median) and measures of dispersion (standard deviation). They were initially tested for normality of distribution with the Kolmogorov-Smirnov tests. Those with normal distribution had their means compared through the Student $t$ test. The medians of the nonparametric data were compared with the Mann-Whitney tests. The binary logistic regression was used to evaluate the associations between the variables predictive of an outcome with HPV present. The magnitude of the association was estimated by calculating the odds ratio $(O R)$ and its respective $95 \%$ confidence interval (CI 95\%). Significant variables and those with a p value lower than $0.150(p<0.150)$ in the univariate analysis were included in the multivariate regression model using the stepwise method. The goodness of fit of the logistic regression model was assessed through the Hosmer-Lemeshow test by seeking $p$ values higher than $0.80(p>0.80)$. Associations with $p$ values lower than $0.05(p<0.05)$ were deemed statistically significant.

\section{Ethics}

The Research Ethics Committee of the Hospital das Clínicas da Faculdade de Medicina da Universidade de São Paulo approved the present study (presentation certificate for ethical appraisal number 65511617.0.0000.0068). An informed consent statement was waived because the project was a retrospective study with data retrieved from the patients' medical histories and there was no direct contact with the patients. All precautions were taken to protect the privacy of the research subjects and the confidentiality of personal information. The hospital's database identifies patients by numbers. Soon, the names of the women became anonymous to the researchers.

\section{Results}

The data from 404 pregnant adolescents were analyzed. Four of the patients were excluded given the lack of access to their medical histories, and 97 of them because they missed the Pap smear test. Of the 303 pregnant adolescents included in the study, $153(50.50 \%)$ tested positive for high-risk HPV, and 150 tested negative.

An overall analysis of the group showed that the mean age of the participants was $15.30 \pm 1.22$ (range: 11-18 years) and the average number of years of schooling was $9.08 \pm 1.79$ (range: $4-14$ years). Most of the adolescents $(83.50 \%)$ were married or cohabited or were single, but had a partner. The partners' mean age was 20.4 (range: 13-47 years). A large proportion of the adolescents was Catholic (44.37\%) or Evangelical (33.44\%) whose monthly family income was less than 5 Brazilian minimum salaries, that is, less than USD 1500 per month (55\%). Of those stating they were religious, only $42.21 \%$ (103/244) declared they actually practiced their religion.

At the beginning of prenatal care, $10.56 \%$ reported the habit of alcohol consumption and another $10.56 \%$ declared they had the habit of smoking. Also, $7.92 \%$ stated they used or had used marijuana, and 1.32\%, cocaine. Most adolescents had never been to a gynecologist before pregnancy (53.14\%), and more than two-thirds were using some kind of contraceptive method (73,93\%), mainly the male condom (45.36\%), when they became pregnant. The mean of sex frequency (per week) was $1.74 \pm 1.80$ and the mean of the time span of sexual activity (in months) prior to the pregnancy was 17.98 \pm 13.14 (range: $1-84$ ). The average number of partners up to the time of the interview was $1.82 \pm 1.64$ (range: 1-14), while the mean age of the patients at coitarche (first sexual intercourse) was $13.86 \pm 1.217$ years (range: $9-17$ years).

One adolescent (0.33\%) presented a high-grade squamous intraepithelial lesion (HSIL) on her Pap smear test, while 29 (9.57\%) presented a low-grade squamous epithelial lesion (LSIL) and 23 (7.59\%) presented atypical squamous cells of undetermined significance (ASC-US), totaling 17.49\% of abnormal Pap smears.

From the demographic perspective, a comparison between the subgroup of oncogenic HPV patients and those without HPV shows that the patients with a viral infection had comparatively little schooling $(p=0.021)$ and were single $(O R=2.15, I C 95 \%=1.14-4.06, p=0.018)(T a b l e ~ 1)$. Among the pregnant adolescents with HPV, there was a tendency, with borderline significance in the univariate analysis, toward being younger $(p=0.099)$, having more tobacco smokers $(0.068)$, having more cocaine users $(p=0.140)$, having more sexual partners in their lifetime ( $p .068)$, having less sex per week ( $p=0.084)$, and having less control over the number of previous gynecological consultations $(p=0.122)$ (Tables 1 and 02$)$. As for sociodemographic characteristics, there was no statistical difference between pregnant adolescents with HPV and those without a diagnosis of HPV regarding the following variables: age $(p=0.099)$, age of partners $(p=0.637)$, practice of any religion $(p=0.465)$, family income, alcohol consumption before pregnancy $(O R=1.73, I C 95 \%=0.81-3.68, p=0.149)$ tobacco use before pregnancy $(O R=2.01, I C 95 \%=0.93-4.33, p=0.068)$ and cocaine use before pregnancy $(O R=9.06,95 \% \mathrm{Cl}=0.48-169.7, p=0.140)(T a b l e ~ 1)$. As for gynecological and obstetric history, there was no statistical difference between pregnant adolescents with HPV and those without a diagnosis of HPV regarding the following variables: visit to the gynecologist before pregnancy $(\mathrm{OR}=0.70,95 \% \mathrm{Cl}=0.44-1.10, p=0.122)$, use of contraceptive method before pregnancy, coitarche $(p=0.409)$, number of sexual partners during life $(p=0.068)$, frequency of sexual intercourse per week $(p=0.084)$ and time span of sexual intercourse before pregnancy $(p=0.923)$ (Table 2$)$.

From the standpoint of cervico-vaginal pathology, of the pregnant adolescents diagnosed with oncogenic HPV, 29.93\% (44/147) exhibited cervical cytological abnormalities, whereas only $6.34 \%$ of the adolescents without high-risk HPV showed a cytological abnormality in the cervix. The diagnosis of oncogenic HPV- 
caused cervical infection was associated with both the ASC-US (OR=5.13, Cl 95\%=1.71-16.54) and the LSIL (OR=9.23, Cl 95\%= 2.80-30.39) findings. Although there was only one HSIL case, this one case appeared to be related to the presence of oncogenic HPV (Table 3).

When we evaluated the clinical characteristics of pregnant women, we observed that the profile of vaginal secretions $(p=0.744)$, weight $(p=0.767)$ and $B M I$ before pregnancy $(p=0.560)$ did not show any statistical difference between adolescents with HPV and those without a diagnosis of HPV. When we evaluated the laboratory characteristics of the pregnant women, we observed that there was no statistically significant difference between the groups of adolescents regarding the microbiology profile observed in oncotic colpocytology (Table 3).

As for obstetric outcomes, $55.21 \%$ of the overall group of pregnant adolescents underwent a vaginal delivery without instrument and $30.21 \%$ underwent a cesarean section. Interestingly, the oncogenic HPV infection did not interfere with the type of delivery nor with the neonatal result as shown in Table 04. There was no statistical difference between pregnant adolescents with HPV and those without a diagnosis of HPV regarding the following outcomes: type of delivery, prematurity $(O R=1.39,95 \% \mathrm{Cl}=0.53-3.61, p=0.497)$, gestational age at birth $(p=0.249)$, birth weight $(p=0.243)$, APGAR score in the first minute of life $(p=0.538)$, APGAR score in the fifth minute of life $(p=0.096)$, APGAR score in the tenth minute of life $(p=0.352)$, length of stay in the nursery ( $p=0.374)$, ph in arterial blood gas analysis of the umbilical cord $(p=0.725)$ and number of prenatal care visits $(p=0.205)($ Table 4$)$.

A multivariate analysis of the data was carried out to determine the risk factors independently associated with oncogenic HPV-caused cervical infection. Schooling (years of study) turned out to be an independent factor for protection against high-risk HPV-caused cervical infection $(p=0.032,0 R=0.847, C l$ $95 \%=0.728-0.986)$. The number of sexual partners in the patient's lifetime $(\mathrm{p}=0.027, \mathrm{OR}=1.268, \mathrm{Cl} 95 \%=1.028-1.564)$ and having a religion as opposed to not having one $(p=0.029, O R=2.054, C I 95 \%=1.077-3.918)$ were also shown to be independent risk factors. In the final model, adjustments were made for weekly frequency of sexual intercourse and marital status (single with or without a partner, married, or informally married). This model proved to be highly adequate to predict the final event ( $p=0.914$ on the Hosmer and Lemeshow test). The other variables were not independent predictors of a diagnosis of cervical high-risk HPV (Table 5).

\section{Discussion}

This study has reported a $50.5 \%$ prevalence of cervical infection caused by high-risk oncogenic HPV among its 303 pregnant adolescents. In the literature, the prevalence of oncogenic HPV among pregnant women ranges from $5.8 \%$ to $51.7 \%$ [25,29]. On the other hand, the prevalence that was found seems not to differ from the observed rate at the same clinic ten years previously, that of $51.7 \%$, in a study with 60 pregnant adolescents [25]. Nevertheless, in the medical literature, the frequency of high-risk HPV on the cervix among adult women tends to be lower than that found among the adolescents in the present study $[10,12,15,20,21,26,29-39]$

Such a high prevalence of oncogenic HPV among pregnant adolescents prompts us to ponder the risk of not having them undergo a Pap smear as most recently recommended by the Brazilian Ministry of Health. The present policy is to limit the Pap smear to women aged 25 years or older in accordance with a few international protocols. The present study presents rates of colpocytological changes of $17.5 \%$, with $10 \%$ of intraepithelial lesions, which are higher than that reported in most of the most recent studies of the Brazilian population, whose frequencies vary between $2.56 \%$ and $10.23 \%$ [40-44]. These are rates not to be overlooked.

Certainly, vaccination of preadolescents and adolescents against HPV is an important public health action, which should lead to lower rates of HPV-caused infection and cytopathological abnormalities in such patients. However, despite the fact that government vaccination in Brazil began in March 2014 , our infection rates remain high when compared to previous data. In a study carried out with 152 pregnant adolescents in a town approximately $90 \mathrm{~km}$ from São Paulo, not only was low adherence to the vaccination program found (only 44\%), but also a remarkable ignorance of the ways to avoid being infected by HPV (66\% did not know how HPV was transmitted) [45].

Furthermore, the detection of LSIL in the oncotic colpocytology of pregnant adolescents was strongly associated with the presence of oncogenic HPV ( $\mathrm{p}<$ $0.001, \mathrm{OR}=9.23, \mathrm{Cl} 95 \%=2.80-30.39)$ and of ASC-US $(\mathrm{p}=0.004, \mathrm{OR}=5.31, \mathrm{Cl} 95 \%=1.71-16.54)$. This result is in consonance with the current literature $[1,4,8,9]$.

A tendency was observed toward an association between a diagnosis of HSIL and the occurrence of high-risk cervical HPV $(p=0.371, \mathrm{OR}=4.40, \mathrm{Cl} 95 \%=0.17-$ 113.1). No association was observed between the diagnosis of HSIL and the occurrence of high-risk cervical $\mathrm{HPV}(\mathrm{p}=0.371, \mathrm{OR}=4.40,95 \% \mathrm{Cl}=0.17-113.1)$. It was not statistically significant, though, most likely because there was only one case of HSIL among the 303 women assessed in the present study. As it is an infrequent event, a much larger cohort would be necessary to show a statistical connection between oncogenic HPV-caused infection and the presence of HSIL. As a matter of fact, such a link has already been well established in the literature.

Evaluation of the risk factors associated with an infection caused by oncogenic HPV revealed that less schooling, measured as fewer years of study, turned out to be an independent risk factor for the disease in pregnant adolescents. There is similar evidence in the literature [11,15].

A large number of partners in an adolescent's lifetime was also identified as a predictor of oncogenic HPV-caused cervical infection. There is evidence in the literature to corroborate this finding $[11,16,17,36,37,39]$.

The practice of a religion stood out as well as an independent risk factor for high-risk cervical HPV. There are no similar reports in the literature. This finding may be linked to the fact that women with religious beliefs show a behavioral pattern which differs from that of women with no such beliefs. However, one would imagine, at least in theory, that religion would encourage healthy behaviors and self-care, an expectation that runs counter to the findings of this research. 
One might say that adolescents with religious beliefs are at a greater disadvantage in terms of socioeconomic status. But this was not the case. These girls had a higher mean of school years $(p=0.009,9.20$ vs. 8.55 years $)$ and higher rates of a family income, which was over two minimum salaries $(p=0.045,0 R=$ $2.27, \mathrm{Cl} 95 \%=1.06-4.84)$. On the other hand, they showed a great tendency toward abnormal vaginal secretion, which was greenish, yellowish, or grayish, as revealed by a speculum exam $(p=0.085, O R=3.88, C l 95 \%=0.89-16.94)$, when compared to the girls without religious beliefs. There was also no statistically significant difference between the group of adolescents with some religious belief and the group without any religious belief regarding the presence of abnormal vaginal discharge (greenish or yellowish or grayish) in the specular examination performed during the prenatal consultation $(\mathrm{p}=0.085, \mathrm{OR}=3.88, \mathrm{Cl}$ $95 \%=0.89-16.94)$. Besides, most of the adolescents who declared a belief in religion denied they actually practiced it $(141 / 244=57.78 \%)$, which could signify an attitude of passivity, along with disinterest in or indifference to life. These findings, therefore, add to the uncertainty about the factors which could explain the association between religious beliefs and oncogenic HPV-caused infection. Additional qualitative studies might provide a better assessment of the reasons for such a connection.

Additionally, being a single pregnant woman without a steady partner was also a risk factor in univariate analysis $(p=0.018, \mathrm{OR}=2.15, \mathrm{Cl}=1.14-4.06)$; however, this was not confirmed by the multivariate analysis $(p=0.141, \mathrm{OR}=1.651, \mathrm{Cl}=0.846-3.222$ ). There is similar evidence in the literature $[10,13,33,36,37]$. This outcome may have resulted from the fact that patients without a stable relationship tend to have a pattern of sexual activity which is different from that which has been observed in adolescents with a steady partner.

None of the obstetric outcome variables turned out to be statistically significant when groups were compared. There is similar evidence in the literature [46]. However, other studies demonstrate an association between cervical HPV infection and the occurrence of some adverse obstetric outcomes such as: premature birth, preterm premature rupture of membranes, intrauterine growth restriction, low birth weight and fetal death [47-49]. Nonetheless, the high-risk HPV-infected pregnant adolescents showed a tendency toward delivering lower-weight newborns $(p=0.243)$ and paying a smaller number of prenatal care visits $(p=0.205)$.

Since this was a hospital-based study, the study sample may not correspond exactly with the general community. Another point which may be considered a limitation is the fact that the hospital where this study was carried out assists primarily women of low socioeconomic status, thus preventing the results from being generalized to the overall population.

However, our findings uphold the relevance of the theme, indicating the need for further longitudinal studies in our environment as a means of establishing better public health policies for this specific population.

\section{Conclusions}

The oncogenic HPV-caused cervical infection rate among pregnant adolescents was $50.50 \%$. Less schooling, a larger number of partners in their lifetime, and having a religion were shown to be independent risk factors for a cervical infection caused by high-risk HPV among adolescents. In the univariate analysis, being a pregnant adolescent without a steady partner turned out to be a risk factor of oncogenic cervical HPV. Obstetric outcomes were not statistically different between the groups. The LSIL and the ASC-US colpocytological findings were strongly associated with high-risk cervical HPV. The LSIL, HSIL, and ASC-US rates among adolescents were, respectively, $9.57 \%, 0.33 \%$, and $7.59 \%$, totaling $17.49 \%$ of cytological abnormalities. Such findings point to the need for additional qualitative studies to determine more precisely the type of behavior involved and the best way to address the risk associated with HPV-caused cervical infection during adolescence.

\section{Declarations}

The authors would like to thank all of the pregnant women who participated in the study and all of the employees of the Clínica Obstétrica do Hospital das Clínicas da Faculdade de Medicina da Universidade de São Paulo. All co-authors helped to write the first draft of the manuscript. No payment was made to anyone to produce the manuscript. The authors disclosure that they have no conflicts of interest to declare. The corresponding author would also like to state that everyone who made a significant contribution to this piece of work has been included in the list above.

\section{Competing Interests}

The authors declare that they have no conflicts of interest for the subject of this publication. None of the authors received any benefits, financial or nonfinancial interests, directly or indirectly related to the work submitted for publication

\section{Author Contributions}

Henrique Diório de Souza: Conceptualization, Formal analysis, Writing - original draft

Adriana Lippi Waismann: Data curation

Giselle Rodrigues Mota Diório: Writing - original draft

Stela Verzinhasse Peres: Formal analysis, Statistical analysis

Rossana Pulcineli Vieira Francisco: Supervision, Project administration

Marco Aurélio Knippel Galletta*: Supervision, Project administration, Conceptualization, Data curation, Writing - review \& editing 
* Corresponding Author

All authors reviewed the article

\section{References}

1. Berek, Jonathan S; Novak, Edmund R (2012). Berek and Novak's Gynecology, 15th Edition. Lippincott Williams and Wilkins, Philadelphia, USA.

2. Bauer HM, Ting Y, Greer CE, Chambers JC, Tashiro CJ, Chimera J, et al. (1991). Genital Human Papillomavirus Infection in Female University Students as Determined by a PCR-Based Method. JAMA: The Journal of the American Medical Association 265(4):472-7.

3. Lorincz AT, Reid R, Jensen AB, Greenberg MD, Lancaster W, Kurman RJ (1992). Human papillomavirus infection of the cervix: Relative risk associations of 15 common anogenital types. Obstetrics and Gynecology 79(3):328-37.

4. International Association for Research on Cancer (2007). Monograph on human papillomaviruses. IARC Monographs on the Evaluation of Carcinogenic Risks to Humans - WHO [Internet] 90:46-179. Available from: http://monographs.iarc.fr/ENG/Monographs/vol90/index.php

5. Koss LG, Durfee GR (1956). Unusual patterns of squamous epithelium of the uterine cervix: cytologic and pathologic study of koilocytotic atypia. Annals of the New York Academy of Sciences 63(6):1245-61.

6. Bray F, Ferlay J, Soerjomataram I, Siegel RL, Torre LA, Jemal A. Global cancer statistics 2018: GLOBOCAN estimates of incidence and mortality worldwide for 36 cancers in 185 countries. CA: A Cancer Journal for Clinicians. 2018;68(6):394-424.

7. Instituto Nacional do Câncer/[National Cancer Institute] (2020). Atlas On-line de Mortalidade/[Online Atlas of Mortality] [Internet]. Available from: https://mortalidade.inca.gov.br/MortalidadeWeb/pages/Modelo01/consultar.xhtml;jsessionid=5BF0FAFD8C1F3F33D8773796CD60C303\#panelResultadc

8. Ho GYF, Bierman R, Beardsley L, Chang CJ, Burk RD (1998). Natural history of cervicovaginal papillomavirus infection in young women. New England Journal of Medicine 12;338(7):423-8.

9. Nobbenhuis MAE, Walboomers JMM, Helmerhorst TJM, Rozendaal L, Remmink AJ, Risse EKJ, et al. (1999). Relation of human papillomavirus status to cervical lesions and consequences for cervical-cancer screening: A prospective study. Lancet 354(9172): 20-5.

10. Ronco G, Ghisetti V, Segnan N, Snijders PJF, Gillio-Tos A, Meijer CJLM, et al. (2005). Prevalence of human papillomavirus infection in women in Turin, Italy. European Journal of Cancer. 41(2):297-305.

11. Zhang R, Shi TY, Ren Y, Lu H, Wei ZH, Hou WJ, et al. (2013). Risk factors for human papillomavirus infection in Shanghai suburbs: A population-based study with 10,000 women. Journal of Clinical Virology 58(1):144-8.

12. Molano M, Posso H, Weiderpass E, van den Brule AJC, Ronderos M, Franceschi S, et al. (2002). Prevalence and determinants of HPV infection among Colombian women with normal cytology. British Journal of Cancer 87(3):324-33.

13. Thomas JO, Herrero R, Omigbodun AA, Ojemakinde K, Ajayi IO, Fawole A, et al. (2004). Prevalence of papillomavirus infection in women in Ibadan, Nigeria: A population-based study. British Journal of Cancer 90(3):638-45.

14. Tran LTH, Tran LT, Bui TC, Le DTK, Nyitray AG, Markham CM, et al. (2015). Risk factors for high-risk and multi-type Human Papillomavirus infections among women in Ho Chi Minh City, Vietnam: A cross-sectional study. BMC Women's Health 15(1):1-9.

15. Kliucinskas M, Nadisauskiene RJ, Minkauskiene M (2006). Prevalence and risk factors of HPV infection among high-risk rural and urban Lithuanian women. Gynecologic and Obstetric Investigation 62(3):173-80.

16. Río-Ospina L del, León SCS de, Camargo M, Sánchez R, Mancilla CL, Patarroyo ME, et al. (2016). The prevalence of high-risk HPV types and factors determining infection in female colombian adolescents. PLoS One 11(11):1-15.

17. Tarkowski TA, Koumans EH, Sawyer M, Pierce A, Black CM, Papp JR, et al. (2004). Epidemiology of Human Papillomavirus Infection and Abnormal Cytologic Test Results in an Urban Adolescent Population. The Journal of Infectious Diseases 189(1):46-50.

18. Herrera-Ortiz A, Conde-Glez CJ, Olamendi-Portugal ML, García-Cisneros S, Plett-Torres T, Sánchez-Alemán MA (2018). College women, HPV genotyping and sexual behavior before HPV vaccination: Results from samples stored for a long time. Journal of Infection and Public Health 11(2):286-9.

19. Uyen J, Lam H, Rebolj M, Dugué P-A, Bonde J, von Euler-Chelpin M, et al. (2014). Condom use in prevention of Human Papillomavirus infections and cervical neoplasia: systematic review of longitudinal studies. J Med Screen 21(1):38-50.

20. Beby-Defaux A, Bourgoin A, Ragot S, Battandier D, Lemasson JM, Renaud O, et al. (2004). Human Papillomavirus Infection of the Cervix Uteri in Women Attending a Health Examination Center of the French Social Security. Journal of Medical Virology 73(2):262-8.

21. Richter K, Becker P, Horton A, Dreyer G (2013). Age-specific prevalence of cervical human papillomavirus infection and cytological abnormalities in women in Gauteng Province, South Africa. South African Medical Journal 103(5):313-7.

22. Mościcki AB, Palefsky J, Gonzales J, Schoolnik GK (1990). Human papillomavirus infection in sexually active adolescent females: Prevalence and risk factors. Pediatric Research 28(5):507-13.

23. Jacobson DL, Womack SD, Peralta L, Zenilman JM, Feroli K, Maehr J, et al. (2000). Concordance of human papillomavirus in the cervix and urine among inner city adolescents. Pediatric Infectious Disease Journal 19(8):722-8.

24. Collins S, Mazloomzadeh S, Winter H, Blomfield P, Bailey A, Young LS, et al. (2002). High incidence of cervical human papillomavirus infection in women during their first sexual relationship. BJOG: An International Journal of Obstetrics and Gynaecology 109(1):96-8.

25. Santos FE (2006). Human papillomavírus identification by hybrid capture II technique in pregnant teenagers: comparison with conventional, liquid-based Pap test and colposcopic findings. Revista Brasileira de Ginecologia e Obstetrícia (RBGO) 28(10):625-6. 
26. Schmeink CE, Melchers WJG, Hendriks JCM, Quint WGV, Massuger LF, Bekkers RLM (2012). Human papillomavirus detection in pregnant women: A prospective matched cohort study. Journal of Women's Health 21(12):1295-301.

27. Salcedo MMBP, Damin APS, Agnes G, Pessini SA, Beitune P el, Alexandre COP, et al. (2015). Prevalence of human papillomavirus infection in pregnant versus non-pregnant women in Brazil. Archives of Gynecology and Obstetrics 292(6):1273-8.

28. Smith EM, Johnson SR, Jiang D, Zaleski S, Lynch CF, Brundage S, Anderson RD, Turek LP (1991). The association between pregnancy and human papilloma virus prevalence. Cancer Detect Prev. 15(5):397-402.

29. Chan PKS, Chang AR, Tam WH, Cheung JLK, Cheng AF (2002). Prevalence and genotype distribution of cervical human papillomavirus infection: Comparison between pregnant women and non-pregnant controls. Journal of Medical Virology 67(4):583-8.

30. Ginindza TG, Dlamini X, Almonte M, Herrero R, Jolly PE, Tsoka-Gwegweni JM, et al. (2017). Prevalence of and associated risk factors for high risk human papillomavirus among sexually active women, Swaziland. PLoS One 12(1):1-18.

31. Brown CR, Leon ML, Muñoz K, Fagioni A, Amador LG, Frain B, et al. (2009). Human papillomavirus infection and its association with cervical dysplasia in Ecuadorian women attending a private cancer screening clinic. Brazilian Journal of Medical and Biological Research 42(7):629-36.

32. Datta SD, Koutsky LA, Ratelle S, Unger ER, Shlay J (2008). Annals of Internal Medicine Article Human Papillomavirus Infection and Cervical Cytology in Women Screened for Cervical Cancer in the United States, 2003 - 2005. Annals of Internal Medicine 148(7):493-500.

33. Giuliano AR, Papenfuss M, Schneider A, Nour M, Hatch K (1999). Risk factors for high-risk type human papillomavirus infection among Mexican-American women. Cancer Epidemiology Biomarkers and Prevention 8(7):615-20.

34. Confortini M, Carozzi F, Zappa M, Ventura L, lossa A, Cariaggi P, et al. (2010). Human papillomavirus infection and risk factors in a cohort of Tuscan women aged 18-24: Results at recruitment. BMC Infectious Diseases 10:157-168.

35. Argyri E, Papaspyridakos S, Tsimplaki E, Michala L, Myriokefalitaki E, Papassideri I, et al. (2013). A cross sectional study of HPV type prevalence according to age and cytology. BMC Infectious Diseases 13(1):2-9.

36. Brassard P, Jiang Y, Severini A, Goleski V, Santos M, Chatwood S, et al. (2012). Women in the Northwest Territories. Can J Public Health 103(4):e282-7.

37. Branstetter AJ, McRee AL, Reiter PL (2017). Correlates of Human Papillomavirus Infection Among a National Sample of Sexual Minority Women. Journal of Women's Health 26(9):1004-11.

38. Wang X, Ji Y, Li J, Dong H, Zhu B, Zhou Y, et al. (2018). Prevalence of human papillomavirus infection in women in the Autonomous Region of Inner Mongolia: A population-based study of a Chinese ethnic minority. Journal of Medical Virology 90(1):148-56.

39. Balanda M, Quiero A, Vergara N, Espinoza G, Martín HS, Rojas G, et al. (2016). Prevalence of human papillomavirus infection among women presenting for cervical cancer screening in Chile, 2014-2015. Medical Microbiology and Immunology 205(6):585-94.

40. Gontijo RC, Derchain SFM, Montemor EBL, Sarian LOZ, Serra MMP, Zeferino LC, et al. (2005). Pap smear, hybrid capture II, and visual inspection in screening for uterine cervical lesions. Cadernos de saúde pública 21(1):141-9.

41. Rodrigues DA, Pereira ÉR, Oliveira LS de S, Speck NM de G, Gimeno SGA (2014). Prevalence of cytological atypia and high-risk human papillomavirus infection in Panará indigenous women in Central Brazil. Cadernos de Saude Publica 30(12):2587-93.

42. Augusto EF, dos Santos LS, Oliveira L do H dos S (2014). Deteç̧ão do papilomavírus humano em citologias cervicais de mulheres atendidas no Programa Saúde da Família. Revista Latino-Americana de Enfermagem 22(1):100-7.

43. Silva EP, Vietta GG, Golfetto L, Zonta MA, Gularte ER, Menezes ME, et al. (2015). Frequency and genotyping of human papillomavirus in women submitted to cytology. DST j bras doenças sex transm. 27 (1-2): 22-8.

44. Barbosa IR, Rodrigues DS, Ferreira LHA, Borges LL, Ribeiro AA (2021). Association Between Bacterial Vaginosis and Cytological Abnormalities in Cytopathological Exams Analyzed in a Laboratory School of Goiânia-GO. Revista Brasileira de Cancerologia 67(1):e-081080.

45. Tanaka EZ, Kamizaki SS, Quintana SM, Pacagnella RDC, Surita FG (2019). Knowledge of Pregnant Adolescents about Human Papillomavirus. Revista Brasileira de Ginecologia e Obstetricia (RBGO) 41(5):291-7.

46. Nimrodi M, Kleitman V, Wainstock T, Gemer O, Meirovitz M, Maymon E, et al. (2018). The association between cervical inflammation and histologic evidence of HPV in PAP smears and adverse pregnancy outcome in low risk population. European Journal of Obstetrics and Gynecology and Reproductive Biology 225:160-5.

47. Niyibizi J, Niyibizi J, Zanré N, Mayrand MH, Mayrand MH, Mayrand MH, et al. (2020). Association between Maternal Human Papillomavirus Infection and Adverse Pregnancy Outcomes: Systematic Review and Meta-Analysis. Journal of Infectious Diseases 221(12):1925-37.

48. Pandey D, Solleti V, Jain G, Das A, Shama Prasada K, Acharya S, et al. (2019). Human Papillomavirus (HPV) infection in early pregnancy: Prevalence and implications. Infectious Diseases in Obstetrics and Gynecology. 2019: 4376902. DOI: 10.1155/2019/4376902.

49. Cho GJ, Min KJ, Hong HR, Kim SW, Hong JH, Lee JK, et al. (2013). High-risk human papillomavirus infection is associated with premature rupture of membranes. BMC Pregnancy and Childbirth 13:173-7.

\section{Tables}

Table 1. Association between sociodemographic variables and oncogenic HPV-caused infection in pregnant adolescents- univariate analysis 


\begin{tabular}{|c|c|c|c|c|}
\hline \multirow[t]{2}{*}{ Characteristics } & \multicolumn{4}{|l|}{ Oncogenic HPV } \\
\hline & Positive (Mean $\pm S D^{\mathrm{b}}$ or\%) & Negative (Mean $\pm S D^{\mathrm{b}}$ or\%) & $\mathrm{OR}^{\mathrm{c}}\left(\mathrm{Cl} \mathrm{d}^{\mathrm{9}} \mathrm{5} \%\right)$ & $\mathrm{p}$ value \\
\hline Age (years) & $15.18( \pm 1.33)$ & $15.41( \pm 1.09)$ & & 0.099 \\
\hline Partner's age (years) & $20.56( \pm 4.35)$ & $20.33( \pm 4.08)$ & & 0.637 \\
\hline Schooling (years of study) & $8.84( \pm 1.74)$ & $9.32( \pm 1.81)$ & & $0.021^{*}$ \\
\hline Marital status & & & & $0.018^{*}$ \\
\hline - Stable relationship or single with partner & $120(78.43)$ & $133(88.67)$ & 1 & \\
\hline \multicolumn{5}{|l|}{ - Single without partner } \\
\hline & $33(21.57)$ & $17(11.33)$ & $2.15(1.14-4.06)$ & \\
\hline \multicolumn{5}{|l|}{ Religion } \\
\hline - Catholic & $68(44.74)$ & $66(44)$ & 1 & \\
\hline - Evangelical & $55(36.18)$ & $46(30.67)$ & $1.16(0.69-1.95)$ & 0.573 \\
\hline - None & $24(15.79)$ & $34(22.67)$ & $0.69(0.37-1.28)$ & 0.233 \\
\hline - Other & $5(3.29)$ & $4(2.67)$ & $1,21(0.31-4.72)$ & 0.780 \\
\hline \multicolumn{5}{|l|}{ Practice of religion } \\
\hline- no & $104(68)$ & $96(64)$ & 1 & \\
\hline -yes & $49(32)$ & $54(36)$ & $0.84(0.52-1.35)$ & 0.465 \\
\hline \multicolumn{5}{|l|}{ Family income } \\
\hline$-<2 M S^{e}$ & $34(22.52)$ & $35(23.49)$ & 1 & \\
\hline - betweeen 2 and $5 \mathrm{MS}^{\mathrm{e}}$ & $47(31.13)$ & $49(32.89)$ & $0.99(0.53-1.83)$ & 0.967 \\
\hline$\rightarrow 5 M S e$ & $20(13.25)$ & $11(7.38)$ & $1.87(0.78-4.49)$ & 0.159 \\
\hline - not informed & $50(33.10)$ & $54(36.24)$ & $0.95(0.52-1.75)$ & 0.877 \\
\hline \multicolumn{5}{|l|}{ Alcohol consumption before pregnancy } \\
\hline \multicolumn{5}{|l|}{ No } \\
\hline \multirow[t]{2}{*}{ Yes } & $133(86.93)$ & $138(92)$ & & \\
\hline & $20(13.07)$ & $12(8)$ & $1,73(0.81-3.68)$ & 0.149 \\
\hline \multicolumn{5}{|l|}{ Smoking before pregnancy } \\
\hline \multicolumn{5}{|l|}{ No } \\
\hline \multirow[t]{2}{*}{ Yes } & $132(86.27)$ & 139(92.67) & & \\
\hline & $21(13.73)$ & $11(7.33)$ & $2,01(0.93-4.33)$ & 0.068 \\
\hline \multicolumn{5}{|l|}{ Use of cocaine before pregnancy } \\
\hline \multicolumn{5}{|l|}{ No } \\
\hline \multirow[t]{2}{*}{ Yes } & 149 (97.39) & $150(100)$ & & \\
\hline & $4(2.61)$ & $0(0)$ & $9.06(0.48-169.7)$ & 0.140 \\
\hline
\end{tabular}

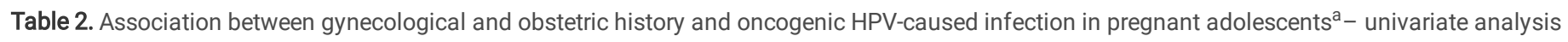




\begin{tabular}{|c|c|c|c|c|}
\hline \multirow[t]{2}{*}{ Characteristics } & \multicolumn{4}{|l|}{ Oncogenic HPV } \\
\hline & Positive (Mean $\pm S D^{b}$ or $\%$ ) & Negative (Mean $\pm S D^{\mathrm{b}}$ or\%) & $\mathrm{OR}^{\mathrm{c}}\left(\mathrm{Cl}^{\mathrm{d}} 95 \%\right)$ & $\mathrm{p}$ value \\
\hline \multicolumn{5}{|l|}{ Visits to the gynecologist before pregnancy } \\
\hline \multicolumn{5}{|l|}{ No } \\
\hline \multirow[t]{2}{*}{ Yes } & $88(57.52)$ & $73(48.67)$ & 1 & \\
\hline & $65(42.48)$ & $77(51.33)$ & $0.70(0.44-1.10)$ & 0.122 \\
\hline \multicolumn{5}{|l|}{$\mathrm{CM}^{\mathrm{e}}$ used before pregnancy } \\
\hline -none & $41(26.97)$ & $37(24.67)$ & 1 & \\
\hline - coitus interruptus & $2(1.32)$ & $0(0)$ & $4.52(0.21-97.2)$ & 0.335 \\
\hline - hormonal & $41(26.97)$ & $44(29.33)$ & $0.84(0.45-1.56)$ & 0.581 \\
\hline - barrier (condom) & $68(44.74)$ & $69(46)$ & $0.89(0.51-1.55)$ & 0.679 \\
\hline Adequate use of $\mathrm{CM}$ before pregnancy & & & & 0.615 \\
\hline \multicolumn{5}{|l|}{ No } \\
\hline \multirow[t]{2}{*}{ Yes } & $119(77.8)$ & $113(75.3)$ & 1 & \\
\hline & $34(22.2)$ & $37(24.7)$ & $0.87(0.51-1.49)$ & \\
\hline Adequate use of male condom before pregnancy & & & & 0.785 \\
\hline \multicolumn{5}{|l|}{ No } \\
\hline \multirow[t]{2}{*}{ Yes } & $132(86.3)$ & $131(87.3 \%)$ & 1 & \\
\hline & $21(13.7)$ & $19(12.7)$ & $1.10(0.56-2.14)$ & \\
\hline Coitarche & $13.8( \pm 1.26)$ & $13.9( \pm 1.23)$ & & 0.409 \\
\hline \multicolumn{5}{|l|}{ Number of partners in her lifetime } \\
\hline & $2.07( \pm 1.98)$ & $1.71( \pm 1.26)$ & & 0.068 \\
\hline \multicolumn{5}{|l|}{ Frequency of sexual intercourse (per week) } \\
\hline & $1.55( \pm 1.45)$ & $1.93( \pm 2.06)$ & & 0.084 \\
\hline \multicolumn{5}{|c|}{ Time span of sexual relations before pregnancy (in months) } \\
\hline & $17.7( \pm 12.8)$ & $17.8( \pm 13.3)$ & & 0.923 \\
\hline
\end{tabular}

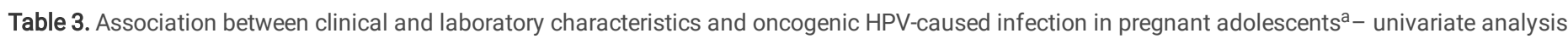




\begin{tabular}{|c|c|c|c|c|}
\hline \multirow[t]{2}{*}{ Characterístics } & \multicolumn{4}{|l|}{ Oncogenic HPV } \\
\hline & Positive (Mean \pm SD $^{\mathrm{b}}$ or $\left.\%\right)$ & Negative (Mean $\pm S D^{b}$ or $\%$ ) & $\mathrm{OR}^{\mathrm{c}}\left(\mathrm{Cl} \mathrm{d}^{\mathrm{9}} 9 \mathrm{\%}\right)$ & p value \\
\hline Weight before pregnancy & $54.30( \pm 9.85)$ & $54.66( \pm 10.4)$ & & 0.767 \\
\hline $\mathrm{BMl}^{\mathrm{e}}$ before pregnancy & $21.32( \pm 3.08)$ & $21.57( \pm 3.77)$ & & 0.560 \\
\hline Secretion & & & & 0.744 \\
\hline -Others & $107(87)$ & $99(88.4)$ & 1 & \\
\hline \multicolumn{5}{|c|}{-Greenish, yellowish, or grayish } \\
\hline & $16(13.0)$ & $13(11.6)$ & $1.14(0.52-2.49)$ & \\
\hline \multicolumn{5}{|c|}{ Microbiology in occ collected at prenatal care } \\
\hline \multicolumn{5}{|l|}{ - Lactobacillus sp } \\
\hline - other cocci or bacilli & $80(54.79)$ & $82(57.75)$ & 1 & \\
\hline - supracytoplasmic bacilli & $15(10.27)$ & $12(8.45)$ & $1.28(0.56-2.91)$ & 0.553 \\
\hline - Candida sp & $34(23.29)$ & $22(15.49)$ & $1.58(0.85-2.94)$ & 0.144 \\
\hline \multirow[t]{2}{*}{ - Trichomonas vaginalis } & $15(10.27)$ & $25(17.61)$ & $0.62(0.30-1.25)$ & 0.179 \\
\hline & $2(1.37)$ & $1(0.70)$ & $2.05(0.18-23.06)$ & 0.561 \\
\hline \multirow{2}{*}{\multicolumn{5}{|c|}{$\begin{array}{l}\text { Result of OCC }{ }^{f} \text { collected at prenatal care } \\
\text { - normal }\end{array}$}} \\
\hline & & & & \\
\hline - benign cell changes & $21(14.29)$ & $31(21.83)$ & 1 & \\
\hline \multirow{2}{*}{$-\mathrm{HSIL}^{\mathrm{g}}$} & $82(55.78)$ & $102(71.83)$ & $1.19(0.63-2.22)$ & 0.591 \\
\hline & $1(0.69)$ & $0(0)$ & $4.40(0.17-113.1)$ & 0.371 \\
\hline- LSIL $^{h}$ & $25(17.0)$ & $4(2.82)$ & $9.23(2.80-30.39)$ & $<0.001^{*}$ \\
\hline - ASC-US ${ }^{i}$ & $18(12.24)$ & $5(3.52)$ & $5.31(1.71-16.54)$ & $0.004^{\star}$ \\
\hline \multicolumn{5}{|c|}{ 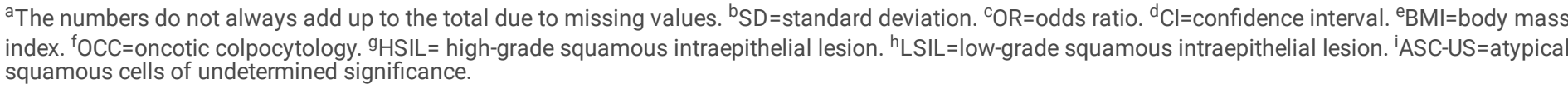 } \\
\hline${ }^{*} p$ value $=$ statistically signi & & & & \\
\hline
\end{tabular}

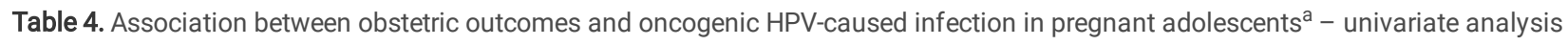




\begin{tabular}{|c|c|c|c|c|}
\hline \multirow[t]{3}{*}{ Characterístics } & \multicolumn{4}{|l|}{ Oncogenic HPV } \\
\hline & Positive & Negative (Mean $\pm S D^{b}$ or $\%$ ) & $\mathrm{OR}^{\mathrm{c}}\left(\mathrm{Cl} \mathrm{d}^{\mathrm{9}} \%\right)$ & $\mathrm{p}$ value \\
\hline & (Mean $\pm S D^{b}$ or \%) & & & \\
\hline \multicolumn{5}{|l|}{ Type of delivery } \\
\hline - Vaginal & $57(57.58)$ & $49(52.69)$ & 1 & \\
\hline - Cesarean & $32(32.32)$ & $26(27.96)$ & $1.06(0.56-2.01)$ & 0.863 \\
\hline - Forceps & $10(10.10)$ & $18(19.35)$ & $0.48(0.20-1.13)$ & 0.093 \\
\hline \multicolumn{5}{|l|}{ Premature birth } \\
\hline- no & $92(89.32)$ & $93(92.08)$ & & \\
\hline -yes & $11(10.68)$ & $8(7.92)$ & $1.39(0.53-3.61)$ & 0.497 \\
\hline Gestational age at delivery & $38.49( \pm 2.34)$ & $38,90( \pm 1.68)$ & & 0.249 \\
\hline \multicolumn{5}{|l|}{ Weight classification of the $\mathrm{NB}^{\mathrm{e}}$} \\
\hline \multicolumn{5}{|l|}{$-A G A^{f}$} \\
\hline \multirow{2}{*}{$-\mathrm{SGA}^{\mathrm{g}}$} & $69(72.63)$ & $70(76.92)$ & 1 & \\
\hline & $23(24.21)$ & $19(20.88)$ & $1.23(0.61-2.45)$ & 0.561 \\
\hline$-L G A^{h}$ & $3(3.16)$ & $2(2.20)$ & $1.52(0.25-9.39)$ & 0.651 \\
\hline Weight at birth & $3010.01( \pm 580.82)$ & $3105.99( \pm 558.42)$ & & 0.243 \\
\hline 1-min APGAR mean score & $8.60( \pm 1.16)$ & $8.46( \pm 1.82)$ & & 0.538 \\
\hline \multicolumn{5}{|l|}{ APGAR score $<7$} \\
\hline \multicolumn{5}{|l|}{ at $1 \mathrm{~min}$} \\
\hline - No & $82(93.2)$ & $78(91.8)$ & 1 & \\
\hline -Yes & $6(6.8)$ & $7(8.2)$ & $0.82(0.26-2.53)$ & 0.724 \\
\hline 5-min APGAR mean score & $9.53( \pm 0.93)$ & $9.20( \pm 1.56)$ & & 0.096 \\
\hline \multicolumn{5}{|l|}{ APGAR score $<7$} \\
\hline \multicolumn{5}{|l|}{ at $5 \mathrm{~min}$} \\
\hline - No & $88(98.9)$ & $80(94.1)$ & 1 & \\
\hline -Yes & $1(1.1)$ & $5(5.9)$ & $0.18(0.02-1.59)$ & 0.123 \\
\hline 10-min APGAR mean score & $9.78( \pm 0.87)$ & $9.62( \pm 1.23)$ & & 0.352 \\
\hline \multicolumn{5}{|l|}{ APGAR score $<7$} \\
\hline \multicolumn{5}{|l|}{ at $10 \mathrm{~min}$} \\
\hline - No & $80(98.8)$ & $78(98.7)$ & 1 & \\
\hline -Yes & $1(1.2)$ & $1(1.3)$ & $0.98(0.06-5.86)$ & 0.986 \\
\hline Stay in nursery (days) & $5.99( \pm 10.01)$ & $4.08( \pm 3.96)$ & & 0.374 \\
\hline \multirow[t]{2}{*}{$\mathrm{pH}$ in umbilical-cord blood gas analysis } & & & & 0.725 \\
\hline & $7.20( \pm 0.79)$ & $7.20( \pm 0.82)$ & & \\
\hline Number of prenatal care visits & $7.67( \pm 2.80)$ & $8.18( \pm 2.64)$ & & 0.205 \\
\hline
\end{tabular}

Table 5. Association between epidemiological variables and oncogenic HPVa-caused infection in pregnant adolescents - multivariate analysis 


\begin{tabular}{|c|c|c|c|c|}
\hline & \multirow[t]{2}{*}{ Significance } & \multirow[t]{2}{*}{$O R^{b}$ adjust } & \multicolumn{2}{|c|}{$95 \% \mathrm{Cl}^{\mathrm{c}}$} \\
\hline & & & Lower & Upper \\
\hline Years of schooling & .032 & .847 & .728 & .986 \\
\hline Number of sexual partners in lifetime & .027 & 1.268 & 1.028 & 1.564 \\
\hline Religion (any religion vs. no religion) & .029 & 2.054 & 1.077 & 3.918 \\
\hline Constant & .408 & 1.886 & & \\
\hline
\end{tabular}

